\title{
GROWTH PERFORMANCE OF Ceriops decandra (GRIFF.) DING HOU PROPAGULES AS INFLUENCED BY PGR - A CONSERVATION EFFORT
}

\author{
M. Gomathinayagam* and A. Arunprasath \\ Department of Botany, Annamalai University, Annamalainagar-608002, Tamilnadu, India \\ *Email: gomsnayagam@yahoo.com
}

\begin{abstract}
Vegetative propagation could be an important advantage and also envisioned to be the best alternative for planting stock production in the absence or lack of seeds. In the Pichavaram mangrove forest Ceriops decandra (Rhizophoraceae) is one of the most endangered species and IUCN also declared this species as near threatened. Propagation of Ceriops decandra, by propagule cuttings, treated with Plant growth regulators is feasible and it was possible to produce three saplings from one propagule. The effect of plant growth regulators like IBA, NAA, $\mathrm{GA}_{3}$ on optimum growth medium and period of nursery care for mangrove saplings of Ceriops decandra were studied and the results revealed that best growth performance was recorded when the cuttings were treated with $\mathrm{GA}_{3}$ alone up to $2000 \mathrm{ppm}$. Combination of NAA and IBA increased the rooting and leaf formation. Among the treatments $\mathrm{GA}_{3}$ enhanced the number of leaves and roots, Shoot and root length, fresh and dry weight of roots increased to larger extent. All the plants are transferred to field in the mangrove forest of Pichavaram, Tamilnadu, India.
\end{abstract}

Key words: Ceriops decandra, Conservation, PGR, Growth, Rooting.

\section{INTRODUCTION}

Mangroves are the only trees amongst a relatively small group of halophytic higher plants that live in the intertidal zones at the interface between land and sea, and are well adapted to survive flooding and high salinity conditions. They are of great significance both in terms of their utilization of forestry and fish produce, and their indirect potential as protecting coastlines and maintaining estuarine ecological balance. Due to several natural and anthropogenic pressures globally, these mangrove forests are being destroyed every year which called for a conservation strategy that can expedite the restoration of degraded areas at a faster pace. In the present day context of intensive afforestation and management of mangrove forestlands it is most important to develop fast and economically viable methods of raising superior stocks.

Habitat loss and fragmentation are seen as the major threats to terrestrial productivity and biodiversity (Soule 1991). In the marine environment, problems of habitat degradation have so far primarily affected vegetated estuarine and 
coastal habitats, including wetlands, salt marshes, seagrass beds, kelp forests and mangroves. (Hatcher et al. 1989, Thorne-Miller and Catena 1991, Suchanek 1994, Norse 1993, Zann 1995). This is critical as these ranks among the most productive of marine systems and most susceptible to decimation. A wide variety of marine organisms, including subsistence and commercially important fisheries are dependent upon vegetated aquatic marine habitats for atleast part of their life cycle (Boesch and Turner 1984). Indirect effects of human impact on the major habitat farming organisms may be even greater than direct effects due to fishing or collecting activities (Ray 1991).

The tropical vast area of mangrove forest were converted in to aquaculture, tin mining and agricultural areas or housing and factory lots (Aksornloae et al. 1992) and some of them were abandoned after these uses. This results in devastated conditions of the coastal area. This habitat has been under severe destruction worldwide at alarming levels (K.Kathiresan and Bingham 2001). Such levels of destruction and habitat fragmentation raise concern about the conservation of mangrove diversity. To augment conservation, management efforts to germinate the unique genotypes has to be made. Restoration of mangrove forests is urgent need to reconstruct original coastal ecosystem. To restore mangrove ecosystem the practical problems includes shortage of viviparous seedlings to plant and the disturbed soil conditions (Komiyama et al. 1996).

Vegetative propagation provides an opportunity to harness and exploit genetic variation directly (Zobel and Talbert 1984). The success of this technique requires proper hormonal balance, temperature, rainfall, humidity, nature of media and light that collectively decide the status of regeneration of roots in cuttings (Dhua and Mitra 1988). Although vegetative propagation is least expensive its success is still limited to mangroves. The present investigation aimed to study the effect of PGR on rooting, root number leaf formation and fresh, dry weight of roots by applying some Growth hormone substances by dipping method on response of Ceriops decandra propagule cuttings.

Ceriops decandra (Griff.) Ding Hou (Family: Rhizophoraceae) locally known as Chirukandal (Tamil) is a medium-sized straight, columnar, evergreen small tree, under favourable conditions reaching up to $3.5 \mathrm{~m}$ in height. This species is highly threatened by removal of mangrove areas for coastal development throughout its range. It is estimated that $26 \%$ of mangrove area has been lost within this species range over a 20 year period (1980-2000) (Duke et al. 2007) In order to compensate such multifarious constrains of natural regeneration, application of vegetative propagation method would be one of the right options for rejuvenating balanced population of Ceriops decandra in the mangrove ecosystems.

\section{MATERIALS AND METHODS}

\section{Collection of plant materials}

Mature and healthy Propagules of Ceriops decandra were collected from adult and reproducing trees in Pichavaram mangrove forest situated at $11^{\circ} 27^{\prime} \mathrm{N}$ Latitude and $79^{\circ} 47^{\prime} \mathrm{E}$ Longitude, in the East coastal region of Tamilnadu, India.

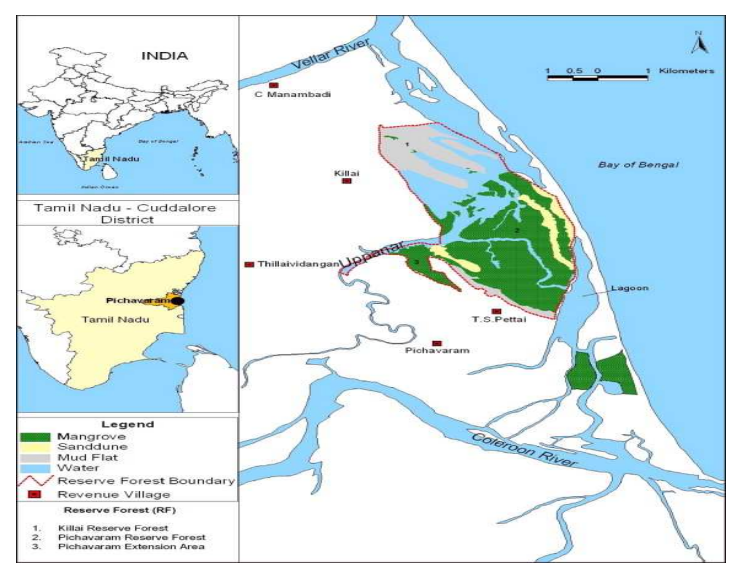

ECOPRINT VOL 22, 2015 


\section{Cutting of propagules}

The collected propagules were cut into 2 to 5 $\mathrm{cm}$ pieces using a clean and sharp knife.

\section{Removal of fungal infestation}

The propagule cuttings were treated with fungicide for the removal of fungal infestations if any. Bovistin and Monochrotophos were mixed in 1:1 proportion in 1 litre distilled water. In the fungicide solution the propagule cuttings were soaked for five min. After soaking it was again washed with distilled water.

\section{Removal of phenol content in propagules cuttings}

Preparation of stock solution: $20 \mathrm{~g}$ of Sodium carbonate $\left(\mathrm{Na}_{2} \mathrm{CO}_{3}\right)$ and $20 \mathrm{~g}$ of Sodium tungstate $\left(\mathrm{Na}_{2} \mathrm{WO}_{4} \cdot 2 \mathrm{H}_{2} \mathrm{O}\right)$ were dissolve successively in 80 $\mathrm{ml}$ distilled water and make up the final volume to $100 \mathrm{ml}$. It is a $20 \%$ stock solution.

Preparation of working solution (10\% and 5\%): $50 \mathrm{ml}$ from the $20 \%$ stock solution and $50 \mathrm{ml}$ of distilled water was added. This gives a $10 \%$ working solution. Another $25 \mathrm{ml}$ of stock solution and $75 \mathrm{ml}$ of distilled water were mixed. This gives a $25 \%$ working solution.

Short-term treatment to remove phenolic compounds: $10 \%$ solution was taken in small cups. The basal portions of the cuttings were kept immersed in the solution for 5-10 min. The treated cuttings were washed with distilled water for about two to three times.

Long-term treatment to remove phenolic compounds: The propagule cuttings were treated in $10 \%$ solution, for about 20-30 min. In 5\% working solution for final treatment. Wash the treated cuttings with distilled water two to three times. Now the propagule cutting is ready for hormone treatment.
Preparation hormone stock solution: 1g of IBA, NAA and add little drops of $1 \mathrm{~N} \mathrm{NaOH}$ were mixed until it dissolves, and $1 \mathrm{gm}$ of $\mathrm{GA}_{3}$ dissolved in $70 \%$ Ethanol made this three solutions with distilled water to $100 \mathrm{ml}$. The strength of this stock solution is $10,000 \mathrm{ppm}$. Using this stock solution we can prepare the hormone treatment solution. Take $10 \mathrm{ml}$ of stock solution and add $90 \mathrm{ml}$ of Distilled water this is $1000 \mathrm{ppm}$ and take $20 \mathrm{ml}$ of stock solution and add $80 \mathrm{ml}$ of Distilled water this is $2000 \mathrm{ppm}$.

\section{Treatment of cuttings}

The plant growth regulators like Indole butyric acid (IBA), Naphthalene acetic acid (NAA) and Gibberellic acid $\left(\mathrm{GA}_{3}\right)$ are used for the hormonal treatment. Propagule cuttings are treated with hormones solutions viz, 1000 and 2000ppm of IBA, $\mathrm{GA}_{3}$ and Combination of IBA 1000ppm and NAA 2000ppm by dipping the propagule cuttings about $12 \mathrm{~h}$.

\section{RESULTS}

Vegetative propagation of $C$. decandra through propagule cuttings

The vegetative propagation of Ceriops propagules produced more number of primary leaves and roots and high root lengths by various combinations of IBA and NAA are graphically presented in Figs. 1, 2, 3, 4 and 5.

\section{Effect on number of primary root production}

Results revealed that among all the hormone treatments (IBA,NAA and $\mathrm{GA}_{3}$ ) 1000 and 2000 ppm, the $\mathrm{GA}_{3}(2000 \mathrm{ppm})$ induced the best root production, while compare to the other treatments. The combination of IBA $1000 \mathrm{ppm}$ and IBA ppm also produced more number of primary roots.

\section{Effect on primary leaf production}

$\mathrm{GA}_{3} 2000 \mathrm{ppm}$ concentration treated cuttings showed highest production of Primary leaves when 
compare to the other treatments. The Combined treatment of IBA 1000 ppm and NAA 2000 ppm also produced more number of primary roots. There was no any response in untreated cuttings.

\section{Effect on primary root length}

Greater root lengths of propagule cuttings were obtained when $\mathrm{GA}_{3} 2000$ ppm alone was used when compared to IBA 1000 ppm and NAA 2000 ppm applied together. When cuttings were treated with all the hormones, but the maximum root length was observed with $\mathrm{GA}_{3} 2000$ ppm.

\section{Effect on fresh weight of roots}

GA3 showed high fresh weight when compared to other hormones and combinations. Cuttings treated with NAA (2000) produced the maximum fresh. But IBA 1000 showed very low fresh weight when compared to other treatments.

\section{Effect on dry weight of roots}

Cuttings treated with both hormones developed the maximum dry weight. This same result obtained in GA3 treated cuttings also. GA3 treated cuttings showed significant result of dry weight when compared to the other hormonal treatments. Finally GA3 (2000) and combination of IBA and NAA showed significant results than the other hormones used separately.

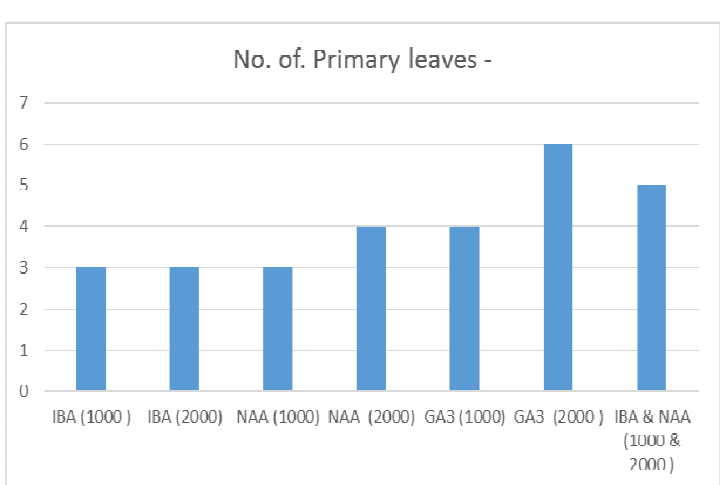

Fig. 1. Effect of growth hormones on number of primary leafs in Ceriops decandra propagule cuttings.

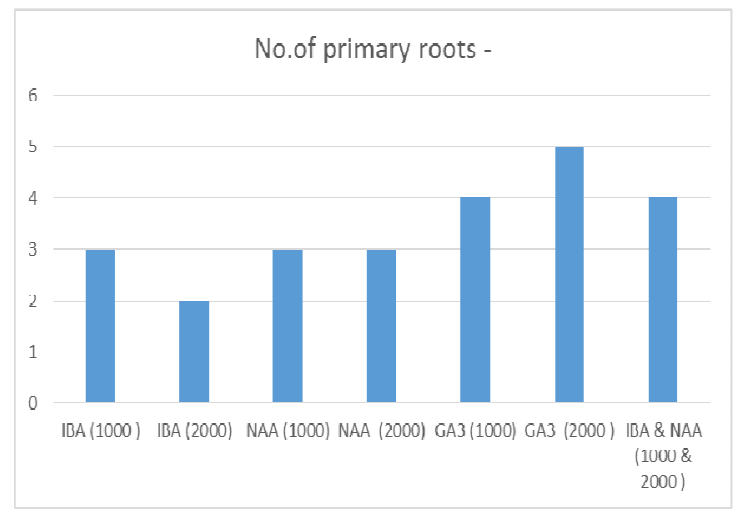

Fig. 2. Effect of Growth hormones on number of primary roots in Ceriops decandra propagule cuttings.

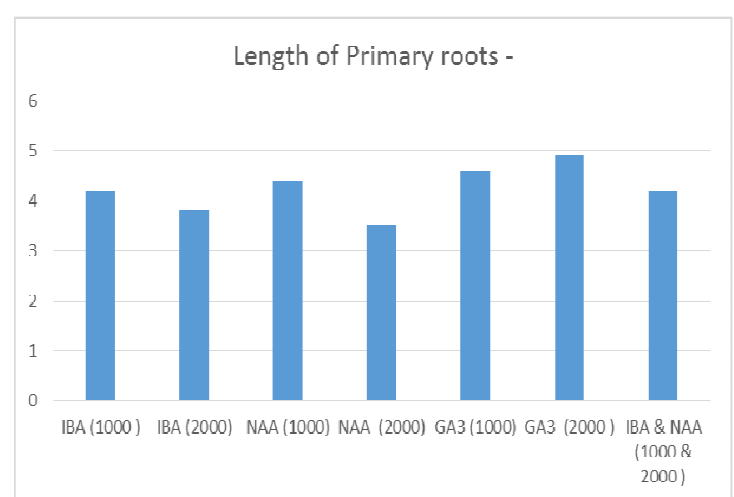

Fig. 3. Effect of growth hormones on length of primary roots in Ceriops decandra propagule cuttings.

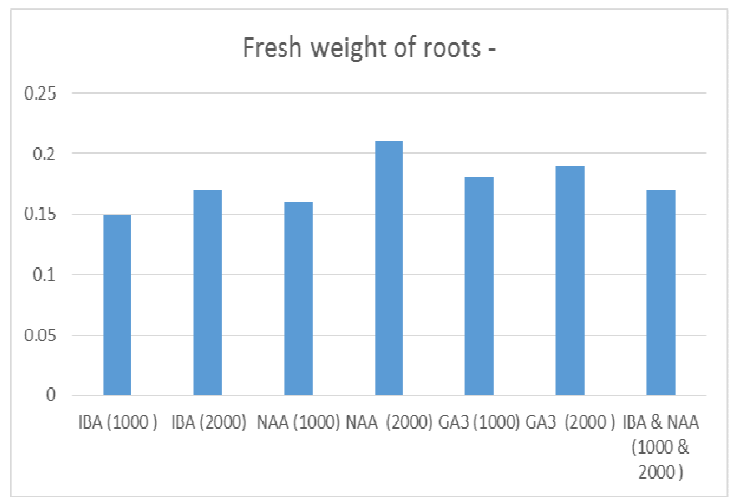

Fig. 4. Effect of growth hormones on root fresh weight of Ceriops decandra propagule cuttings.

ECOPRINT VOL 22, 2015 


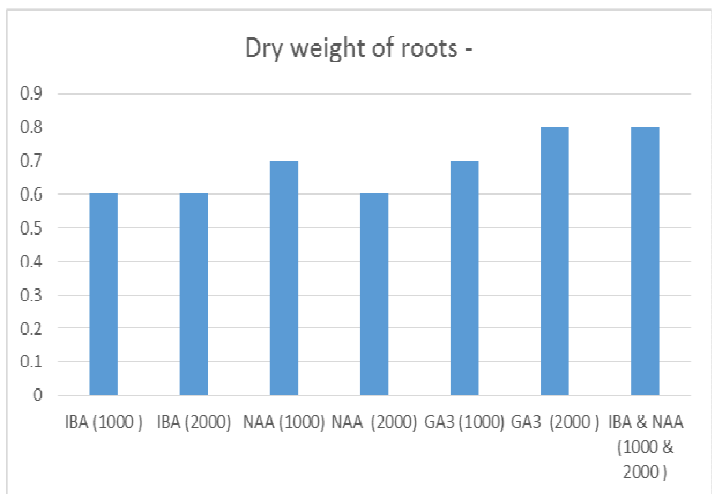

Fig. 5. Effect of growth hormones on root dry weight of Ceriops decandra propagule cuttings.

\section{DISCUSSION}

Vegetative propagation methods produce plants with identical genotype with the mother plant (Selvam et al. 2005). The present study, aimed to produce three saplings from a $20 \mathrm{~cm}$ long C. decandra propagule. Hence growth hormone treated propagule cuttings provide a reasonable means for mass production of $C$. decandra propagules. Combined auxin treatment was reported to have strong effect on the rooting response of stem cuttings/air layers of difficult-toroot species (Basak et al. 1995, Jackson 1986). In the present study, combined treatment with IBA and NAA also produced highest rooting percentage, root number and length in both the types of cuttings over the control. The stimulatory effects of auxins on adventitious rooting of stem cuttings and air layers of several other mangrove and non-mangrove species have been reported earlier (Basak et al. 1995, 2000, Das et al. 1997, Davis and Haissig 1994, Hartmann et al. 1997). The differential root regeneration capacities of different growth hormones individually or in combination, might depend on their respective capacities for the regeneration and elongation of roots (Ghosh and Basu 1974). The large number of root primordia induced by the root promoting hormones act as effective metabolic sinks, drawing on the nutritional reserves of the cuttings for their growth and development (Das et al. 1996). In many of the tree species clonally propagated materials initially grow much faster (Schreiner 1939). Rooting of cuttings and air layering are the common vegetative propagation technique used for tree species. Most importantly for mangrove afforestation, these techniques are not very expensive (Carlton and Moffler 1978). The results showed that $\mathrm{GA}_{3}$ singly was a better rooting hormone than NAA or a combination of IBA and NAA. It was also evident that the beneficial effects of IBA were enhanced with the increase in concentrations up to a certain optimum level. This result is in accordance with earlier reports in Ulmus leavigata by Chauhan and Reddy (1974), Pathak et al. (1975) and Kanwar et al. (1996).Significant effect on the primary root length and number of roots and leaves were earlier recorded in mangroves - $R$. mangle (Smith et al. 1995), and in Avicennia marina (Kathiresan and Moorthy 1994). Selvam et al. (2005) recorded that 93\% rooting response from IBA (1500 ppm) treated $R$. apiculata propagule cuttings, $42 \%$ rooting response from IBA (2500 ppm) treated $R$. apiculata and A. marina air layers, $48 \%$ rooting response from IBA (2000 ppm) treated $R$. apiculata and A. marina and $56 \%$ rooting response from IBA (2000 ppm) treated A. marina stem cuttings. A number of workers also have shown that rooting is facilitated when the carbohydrate reserve foods are in abundance (Rauter 1983, Haissig 1974). $\mathrm{GA}_{3}$ exerts profound effects on fundamental process of plant growth and development. $\mathrm{GA}_{3}$ is widely regarded as a growth promoting compound that positively regulates processes such as seed germination, stem elongation and leaf expansion. (Swain and Singh 2005). However, Banyal and Rai (1983) found that GA3 reversed the inhibition of hypocotyl elongation of Brassica campestris L., under osmotic stress which indicates that the decrease in endogenous concentrations may be a major consequence of salt stress. The exogenous application of gibberellins stimulated stem 
elongation and leaf area expansion in $R$. mangle propagules floating in $35 \mathrm{~g} \mathrm{1-1}$ seawater (Smith et al. 1995). The Auxin induced effect on rooting of cuttings is presumed to be mediated through its effect in mobilizing the reserve food material by enhancing the activity of hydrolytic enzymes (Nanda et al. 1968). $\mathrm{GA}_{3}$ application was reported to increase weight of aerial parts in Viola (Vlahos 1991). Exogenously applied, gibberellin promoted stolon elongation and inhibited tuber formation and increased fresh weight in potato (Xu et al. 1998). Combined auxin treatment was reported to have strong effect on the rooting response of stem cuttings/air layers of difficult-to-root species (Basak et al. 1995, Jackson 1986). In the present study, combined treatment with IBA and NAA also produced highest rooting percentage, root number and length in both the types of cuttings over the controls. The stimulatory effects of auxins on adventitious rooting of stem cuttings and air layers of several other mangrove and non-mangrove species have been reported earlier (Basak et al. 1995, 2000, Das et al. 1997, Davis and Haissig 1994, Hartmann et al. 1997). This study thus establishes good promise of a cost effective and promising technique of propagation for the endangered mangrove species for raising populations of superior clones for planting in seed orchards or directly in the field to aid in our efforts to conserve mangrove species.

\section{ACKNOWLEDGEMENT}

The authors are acknowledge to the University Grant Commission, Government of India, New Delhi for their financial Support during the study period.

\section{REFERENCES}

Banyal, S. and V.K. Rai. 1983. Reversal of osmotic stress effects by gibberellic acid in Brassica campestris. Recovery of hypocotyl growth, protein and RNA levels in the presence of GA. Physiol. Plant 59:111-114.
Basak, U.C, A.B. Das and P. Das. 1995. Metabolic changes during rooting in some cuttings of five mangrove species of Orissa. Plant Growth Regul. 17:141-148.

Basak, U.C, S.G. Mahapatrao and P. Das. 2003. Vegetative propagate on of Aegiceras corniculatum, a tree mangrove: Biochemical and anatomical basis of adventitious rooting. Indian J. Bot. 26:162-167.

Basak, U.C., A.B. Das and P. Das. 2000. Rooting response in stem cuttings from five species of mangrove trees: effect of auxins and enzyme activities. Marine Biol. 136:185-189.

Boesch, D.F. and R.E. Turner. 1984. Dependence of fishery species on salt marshes: The role of food and refuge. Estuaries 7:460-468.

Carlton, J.M. and M.D. Moffler. 1978. Propagation of mangroves by air-layering. Environ. Conserv. 5:147-150.

Carlton, J.M. and M.D. Moffler. 1978. Propagation of mangroves by air-layering. Environ. Conserve. 5:147-150.

Chauhan, K.S. and T.S. Reddy. 1974. Effect of growth regulators and mist on rooting in stem cuttings of plum. Indian Journal of Horticulture 32:229-231.

Das, A.B., U.C. Basak and P. Das 1996. Metabolic changes during rooting in pre-girdled stem cutting, air layering of Heritiera. Botanical Bulletin of Academia Sinica 38:91-95.

Das, P., U.C. Basak and A.B. Das. 1997. Metabolic changes during rooting in pregirdled stem cuttings and air-layers of Heritiera, a common tree mangrove of coastal Orissa. Bot. Bull. Acad. Sinica 38:91-95.

Davis, T.D. and B.E. Haissig. 1994. Biology of adventitious root formation. Plenum Press, New York, 1:343.

Dhua, R.S. and S.K. Mitra. 1988. Mist will not make cuttings root more easily. Indian Horticulture 32:7-9. 
Eganathan, P., C.S. Rao and A. Anand. 2004. Vegetative propagation of three mangrove tree species by cuttings and air layering. Springer Netherlands online (0923-4861 (print) 15729834:281-286.

Gosh, S.K. and R.N. Basu. 1974. Metabolic changes during the regeneration of roots on cuttings. Indian Journal of Biology 12:166168.

Haissig, B.E. 1974. Activity of some glycolytic and pentose phosphate pathway enzymes during the development of adventitious roots. Physiologia Plantarum 55:261-272.

Hartmann, H.T., D.E. Kester, F.T. Davies and R.L. Geneve. 1997. Plant propagation principle and practices, $6^{\text {th }}$ edn. Prentice-Hall of India Private Limited, New Delhi, pp. 276-328.

Hatcher, B.G., R.E. Johannes and A.I. Robertson. 1989. Review of research relevant to the Conservation of shallow tropical marine ecosystems. Oceanogr. Mar. Biol. Ann. Rev. 27:337-414.

Jackson, M.B. 1986. New root formation in plants and cuttings. The Netherlands pp. 163-164.

Kanwar, B.S, S.P. Bharadwaj and G.S. Shamet. 1996. Vegetative propagation of Ulmus laevigata by stem cuttings. Journal of Tropical Forest Science 8:333-338.

Kathiresan, K. and P. Moorthy. 1994. Hormoneinduced physiological responses of tropical mangrove species. Bot. Mar. 37:139-141.

Kathiresan, K. and S. Ravikumar. 1995. Vegetative propagation through air layering in two species of mangroves. Aquatic Botany 50:107-110.

Norse, E.A. 1993. Global Marine Biological Diversity: A Strategy for Building Conservation into Decision Making. Island Press, Washington, USA, 383 pp.

Pathak, R., D. Pandy and U.S. Pandy. 1975. Effect of IBA concentrations and bottom heat on rooting of plum cuttings. Progressive Horticulture 7:17-21.

Rauter, R.M. 1983. Clonal forestry: Its impact on tree improvement and our future forests. Proceedings of the $19^{\text {th }}$ Biennial Meeting of Canadian Tree Improvement Association, Canada, Toronto, pp. 234-239

Ray, G.C. 1991. Coastal-zone biodiversity patterns. Bioscience 41:490-498.

Schreiner, E.J. 1939. The possibility of the clone in the forestry. J. For. 37:61-62.

Selvam, V.R., T. Karunagaran, R. Ramasubramanian, P. Eganathan and A.K. Parida. 2005. Toolkit for Establishing Coastal Bioshield. M.S. Swaminathan Research Foundation, Chennai, 120 p.

Smith, S.M. and S.C. Snedaker. 1995. Developmental responses of established red mangrove, Rhizophora mangle L., seedlings to relative levels of photosynthetically active and ultraviolet radiation. Florida Sci. 58:55-60.

Soule, M.E. 1991. Conservation: tactics for a constant crisis. Science 253:744-750.

Spalding, M., M. Kainuma and L. Collins. 2010. World Atlas of Mangroves, Earth scan.

Suchanek, T.H. 1994. Temperate coastal marine communities: biodiversity and threats. Amer. Zool. 34:100-114.

Swain, S.M. and D.P. Singh. 2005. Tale tales from sly dwarves: novel functions of gibberellins in plant development. Trends Plant Sci. 10:123129.

Thorne-Miller, B.L. and J.G. Catena. 1991. The Living Ocean: Understanding and Protecting Marine Biodiversity. Island Press, Washington, USA, 180pp.

Vlahos, J.C. 1991. Growth and Development in Achimenes Cultivars. Wageningen University.

Xu, X., A.M. Van Lammeren, E. Vermeer and D. Vreugdenhil. 1998. The role of gibberellin, 
$\mathrm{ABA}$ and sucrose in the regulation of potato tuber formation invitro. Plant Physiol. 117:575-584.

Youssef, T. 1997. Approaches in mangrove planting: Some options for Darwin mangroves. Proceedings of the Sixth International Marine Biological Workshop, The Australian Marine Sciences Association, Darwin, Australia, pp. 321-333.
Zann, P.L. 1995. Our Sea, Our Future: Major Findings of the State of the Marine Environment Report for Australia. Published by the Great Barrier Reef Marine Park Authority, for the Department of Environment, Sport and Territories, Australia.

Zobel, B. and J. Talbert. 1984. In: Applied Forest Tree Improvement. Wiley, New York, pp. 159. 